\title{
ANÁLISE DAS AÇÕES AFIRMATIVAS APLICADAS NO TWITTER DO ESPORTE CLUBE BAHIA
}

\section{Affirmative actions applied analysis on Esporte Clube Bahia Twitter Profile}

Análisis de acciones afirmativas aplicadas en Twitter del Esporte Clube Bahia

Iago Alan Maia Peixoto

Especialista em mídias sociais, Centro Universitário Jorge Amado

iagomaia29@gmail.com

Heitor Ferrari Marback

Doutor em Difusão do Conhecimento, Centro Universitário Jorge Amado

hfmarback@gmail.com

Rodrigo Ladeira

Doutor em Administração, Universidade Federal da Bahia - UFBA rodladeira@yahoo.com

\section{Resumo}

O futebol está presente no cotidiano de boa parte da população brasileira, podendo ser interpretado e utilizado como um agente indireto na construção e transformação social de cada indivíduo. Esta pesquisa buscou analisar o impacto de ações afirmativas aplicadas de forma estratégica pelo Esporte Clube Bahia no Twitter, plataforma de redes sociais em que o clube tem maior engajamento. Foi utilizado procedimento metodológico exploratório analítico, a partir da construção de uma pesquisa bibliográfica, norteada pela produção de Margarida Kunsch e Maurício Murad; além do estudo de caso, no qual foram avaliadas as campanhas de ações afirmativas na página “@ecbahia”. Ao final, concluiu-se que a postura adotada trouxe retornos positivos, tanto para a imagem quanto para a rede social da agremiação.

Palavras-chave: Esporte Clube Bahia. Ações afirmativas. Twitter.

\begin{abstract}
This research sought to analyze the impact of affirmative actions applied strategically by Esporte Clube Bahia on Twitter, a social networking platform in which club has the highest engagement. An analytical exploratory methodological procedure was used, based on the construction of a bibliographical research guided by the production of Margarida Kunsch and Maurício Murad; in addition to the case study, in which affirmative action campaigns were evaluated on the page @ecbahia. In the end, it was concluded that the adopted posture brought positive returns for both the image and social network of the association.
\end{abstract}

Key words: Esporte Clube Bahia. Affirmative actions. Twitter. 


\section{Resumen}

Esta investigación buscó analizar el impacto de las acciones afirmativas aplicadas estratégicamente por Esporte Clube Bahia en Twitter, una plataforma de redes sociales en la que el club tiene el mayor compromiso. Se utilizó un procedimiento metodológico exploratorio analítico, basado en la construcción de una investigación bibliográfica guiada por la producción de Margarida Kunsch y Maurício Murad; además del estudio de caso, en el que se evaluaron las campañas de acción afirmativa en la página @ecbahia. Al final, se llegó a la conclusión de que la postura adoptada trajo retornos positivos tanto para la imagen como para la red social de la asociación.

Palabras clave: Esporte Clube Bahia. Acciones afirmativas. Twitter.

\section{INTRODUÇÃO}

Não se pode precisar exatamente onde e quando surgiu o futebol. Relatos apontam que, ao longo da história, japoneses, persas, vikings, latinos, entre outros povos já disputavam modalidades correlativas à prática moderna. Registros mais antigos evidenciam que, em 3.000 a.c., militares da China praticavam um jogo onde se dividiam em duas equipes que tinham como objetivo tocar a "cabeça dos inimigos derrotados em combate", evitando que caísse no chão, até passar por duas hastes fincadas no terreno. Entretanto, somente no século XIV que a modalidade mais popular do mundo surgiu com uma nova roupagem, em meio ao protagonismo político, cultural e social do Império Britânico, no decorrer da Revolução Industrial. Naquele momento, tratava-se de uma ferramenta de darwinismo social, utilizada pela elite local, a fim de contribuir com a hegemonia de um determinado grupo e forjar novos líderes (FRANCO JÚNIOR, 2007).

No entanto, o futebol rompeu barreiras e se transformou na manifestação cultural e esportiva capaz de mobilizar pessoas dos cinco continentes, independentemente do gênero, raça, religião ou classe social, seja através da prática amadora e discussões em conversas de bar ou pelo consumo ligado à categoria profissional, como jogos, camisas, programas esportivos, entre outros.

O interesse pela modalidade esportiva, nos dias atuais, é tanto que, segundo dados divulgados pela Federation Internationale of Football Association (FIFA), entidade máxima do esporte, publicado no site do jornal Extra, quase metade da população mundial $(3,572$ bilhões de telespectadores) assistiu parte de alguma partida da Copa do Mundo de 2018 e mais de 580 milhões de postagens foram produzidas nas mais diversas mídias sociais, entre 
os dias 14 de junho e 15 de julho. Ademais, os perfis da entidade ganharam juntos quase 128 milhões de fãs enquanto a competição acontecia na Rússia.

No Brasil, o cenário também apresenta dados bastante significativos. Segundo o Dossiê Esporte (2006), o futebol é a modalidade preferida de $81 \%$ da população e causa algum tipo de impacto na rotina de $90 \%$ dos brasileiros, através da prática, ida ao estádio ou do acompanhamento dos jogos pelas emissoras de TV e rádio. O forte apelo popular, evidenciado pelos números supracitados, colocou o esporte bretão na posição de poderosa ferramenta de associativismo, interação e de formação de seres políticos.

Embora possua influência na construção identitária, o futebol no país ainda é visto como um espaço conservador. Isso porque os clubes se omitem ou assumem uma postura tímida em relação às demandas cada vez mais efervescentes da sociedade, como o combate à violência doméstica, o machismo, a intolerância racial e religiosa, os direitos dos povos indígenas e a igualdade de gênero. Eis que, na contramão das tradicionais equipes nacionais, o Esporte Clube Bahia criou um Núcleo de Ações Afirmativas (NAA), passando a se posicionar de maneira firme a favor das bandeiras que favorecem setores sociais discriminados.

Diante dos fatos expostos, justificou-se a realização do presente estudo, pela relevância do tema e pela escassez de trabalhos produzidos nesse contexto no país, até o presente momento. Este trabalho teve por objetivo analisar e interpretar as ações afirmativas aplicadas pelo Esporte Clube Bahia em sua principal rede social, o Twitter, além de buscar identificar se esses esforços representaram retorno de imagem para a instituição.

Foram utilizados, como referenciais teóricos, os estudos de Margarida Kunsch acerca das relações públicas, com intuito de analisar profundamente a questão da imagem, e o trabalho de Maurício Murad, para fundamentar a importância da modalidade na nossa sociedade. O procedimento metodológico escolhido foi o exploratório analítico, permitindo esmiuçar territórios pouco mapeados e questões não estruturadas no campo da pesquisa. Para tanto, foi utilizada a pesquisa bibliográfica, através do levantamento do acervo referente ao tema estudado, como livros, artigos científicos e sites, a fim de obter mais conhecimento do assunto. Foi realizado, também, um estudo de caso, que tem caráter de profundidade e detalhamento, por meio da abordagem quali-quantitativa, com cruzamento de levantamento de dados e da análise de evidências das supostas causas dos resultados obtidos. 
Foram analisadas e comparadas as métricas mais significativas de engajamento da conta oficial “@ecbahia” (impressões, retweets ${ }^{1}$, favoritos, respostas, cliques no link ${ }^{2} \mathrm{e}$ número de seguidores), nos períodos referentes a $1^{\circ}$ de janeiro a 30 de junho, dos anos de 2018 e 2019, obtidas junto ao setor de comunicação do clube, através do Twitter Analytcs, ferramenta de gerenciamento da própria rede social. O intuito era compreender se houve crescimento no engajamento em relação ao ano anterior, antes do lançamento das primeiras campanhas. Posteriormente, foi realizada a comparação dos números gerados entre o primeiro e o segundo trimestre de 2019, pois observou-se maior concentração de publicações relacionadas às campanhas de ações afirmativas no período referente a abril, maio e junho. $\mathrm{O}$ intuito foi verificar se há influência clara sobre o comportamento dos usuários. Por fim, foi aplicado formulário de resposta online, através da plataforma Google Forms, cujo link foi disponibilizado entre 10 e 17 de julho de 2019. Tal questionário foi composto por dez perguntas, com nove objetivas, sendo que uma permitia selecionar mais de uma resposta, e uma subjetiva. As questões abrangeram desde as condições socioeconômica a impressões dos usuários acerca dos posts afirmativos. Levando em consideração que o clube possui 2.1 milhões de torcedores ${ }^{3}$, para que o estudo apresentasse representatividade seria necessário obter uma amostra com 601 elementos, considerando um erro amostral de 4\% e nível de confiança de 95\%, além da distribuição da população mais heterogênea. A estratégia para se obter uma quantidade de respostas que garantissem a validade e representatividade ao estudo foi a postagem do questionário no perfil do Twitter de um dos autores, sendo replicada (retwittada) pelo perfil do clube. Assim, de forma aleatória, já que toda a base de seguidores do clube teve acesso ao pedido para responder ao questionário, se atingiu um quantitativo de 624 respondentes.

A análise quantitativa foi feita através da comparação de números absolutos e frequência, tanto das métricas de engajamento quanto das respostas objetivas do formulário. Já a análise qualitativa foi realizada manualmente pela comparação das respostas da pergunta subjetiva, buscando compreender a percepção do público diante dos conteúdos da agremiação na rede social.

\footnotetext{
${ }^{1}$ Termo utilizado exclusivamente no Twitter que se refere ao compartilhamento de uma publicação.

${ }^{2}$ Endereço de uma página na internet.

${ }^{3}$ Segundo o Datafolha, a torcida do Esporte Clube Bahia corresponde a $1 \%$ da população brasileira. O índice representa aproximadamente 2.1 milhões de pessoas no comparativo com a projeção realizada pelo Instituto Brasileiro de Geografia e Estatística (IBGE).
} 


\section{ESPORTE CLUBE BAHIA E NUCLEO DE AÇÕES AFIRMATIVAS}

O Esporte Clube Bahia surgiu em meio as incertezas e instabilidades políticas, sociais e econômicas da sociedade brasileira, a partir da iniciativa de ex-jogadores do Clube Bahiano de Tênis e da Associação Atlética da Bahia, à época tradicionais agremiações locais que encerraram as atividades "em razão da resistência da elite baiana à participação de trabalhadores negros nos times de futebol de Salvador" (LEANDRO, 2011). Apesar da segregação, o processo de transformação da modalidade esportiva ganhou ainda mais força nos anos iniciais do século XX. Como aponta Leandro (2011):

O futebol nasceu elitista e era praticado pelos jovens da burguesia, mas a ascensão do Esporte Clube Ypiranga, nos anos 1920, contribuiu para modificar este perfil. O time amarelo e preto liderou outras agremiações para abrir as portas do futebol aos trabalhadores e aos negros, tornando impraticável, para os clubes da alta sociedade baiana, continuar na disputa. (LEANDRO, 2011; p.16)

Nesse contexto, os atletas que estavam sem atuar se juntaram para realizar partidas amadoras no subúrbio de Salvador e Recôncavo baiano e, após grande sucesso, lançaram oficialmente o Bahia, no dia 1 de janeiro de 1931, em evento que contou com a presença de atletas, profissionais liberais, funcionários públicos, jornalistas, microempresários e estudantes.

O Bahia logo tornou-se o maior vencedor estadual e dono da principal torcida local, principalmente entre os torcedores das camadas mais populares. Em aproximadamente 88 anos foram 48 títulos baianos e três Copa do Nordeste, além da Taça Brasil de 1959 e a Copa União de 1988, como já foi chamado o Campeonato Brasileiro. Embora seja um fenômeno de popularidade nos dias atuais, com aproximadamente 2.1 milhões de torcedores, o Esquadrão de Aço, como também é conhecido, não utilizou sua influência para dialogar e participar da formação sociocultural da população baiana, se mantendo omisso nos momentos históricos nacionais, nos mais diversos âmbitos.

De acordo com dados divulgados pela Pesquisa Nacional por Amostra de Domicílios Contínua (Pnad Contínua), aplicada pelo IBGE em 2017, a população baiana era composta por $81,4 \%$ de negros e pardos naquele ano. Já as mulheres representaram 51,6\% no relatório (PNAD Contínua 2018). Foi a partir da compreensão do cenário que estava inserido que a 
diretoria executiva do clube criou, em março de 2018, o NAA, grupo formado por sócios, conselheiros e funcionários, responsável pela execução de campanhas em apoio às causas sociais ligadas à população negra, LGBT, mulheres, índios, religiões de matrizes africanas etc. Portanto, o NAA surgiu, estrategicamente, com o objetivo de valorizar as minorias e trabalhar na construção de um convívio harmonioso na sociedade contemporânea.

Segundo o presidente Guilherme Bellintani, que está à frente da diretoria executiva do Esporte Clube Bahia desde dezembro de 2017, o futebol é uma ferramenta sociocultural que "pode servir para acentuar o que há de pior na nossa sociedade, como o racismo, as agressões, a violência e a intolerância, mas pode servir de forma diferente, para espalhar cultura, afeto, sensibilidade, melhoria das relações humanas" (BELLINTANI, 2019). Essa linha de pensamento também é defendida pelo sociólogo Maurício Murad (2013), que afirma que o esporte tem "potencial de sociabilidade para ser um processo lúdico que ajuda a reeducar, já que sua lógica desportiva está fundamentada na igualdade de oportunidades, no respeito às diferenças e na assimilação de regras e normas de convivência com o outro" (2013; p. 60).

Ainda de acordo com Murad (2013), o esporte bretão, por se tratar da modalidade mais amada e presente na vida da população nacional, tem capacidade de contribuir diretamente com a redução dos índices de violência, como tráfico de drogas e armas, assassinato, pedofilia, homofobia e crimes raciais, sociais e de gênero.

O futebol, é óbvio, não é panaceia, remédio para todos os males de nosso país, não, claro que não. Se nem a política, a educação ou a justiça conseguiram reduzir nossa dívida social profunda, não será o futebol a fazêlo. Entretanto, devido a sua dimensão e impacto simbólicos, o futebol como "esporte das multidões" pode ajudar (ajudar!) a reduzir as práticas de violência que se generalizam em todo o território brasileiro. (MURAD; 2013, p. 142)

Tendo em vista o cenário apresentado anteriormente, sabe-se que o surgimento do NAA foi um marco importante na realização de ações pontuais, como a criação de uma mascote negra e homenagens à vereadora Marielle Franco e ao capoeirista baiano Romoaldo Rosário da Costa, conhecido popularmente como Moa do Katendê, ambos assassinados por motivações políticas. No entanto, a guinada definitiva dessa militância ocorreu a partir da propagação nas mídias sociais, fato que gerou mais repercussão na imprensa nacional e fomentou debates entre os adeptos. 


\section{MÍDIAS E REDES SOCIAIS}

Desde os primórdios, o ser humano tem necessidade de se comunicar com outras pessoas e, com os passar dos anos, novas ferramentas foram criadas para facilitar as interações. No entanto, foi somente a partir do desenvolvimento tecnológico e do advento da internet, no final do século XX, que surgiram as mídias sociais. Elas são instrumentos de relacionamento que possibilitaram que os usuários criem e propaguem conteúdo através de redes virtuais. Como afirma Castells (2003; p. 109), “cada vez mais, as pessoas estão organizadas não simplesmente em redes sociais, mas em redes sociais mediadas por computador".

As redes sociais existem graças a união de indivíduos que partilham os mesmos desejos, pontos de vistas, valores e objetivos e podem estar presentes nos mais diversificados locais, como bairro, rua, trabalho, escola, etc. Diante das necessidades diárias contemporâneas, as interações acontecem cada vez mais no campo virtual, "a partir de processos contínuos de comunicação que se desenrolam no ambiente chamado, por convenção, de mídia social" (COLNAGO, 2015, p. 06).

A popularização do acesso à internet e a forte presença do futebol no cotidiano dos indivíduos fizeram com que as agremiações esportivas utilizassem as mídias sociais digitais como mais uma forma de socialização, tendo um ponto de contato mais estreito com os seus fãs, modificando o tipo de relacionamento e criando vínculos. Campos, Coimbra e Oliveira (2018) afirmam que a mídia é um campo de batalha onde os atores sociais e políticos disputam espaço e buscam ratificar suas imagens diante do público. Os pesquisadores defendem, através de artigo, que "os meios de comunicação estão em constante disputa para construir imagens públicas dos atores políticos para as audiências. É uma disputa constante entre imagens idealizadas e imagens a serem propagadas” (2018; p. 142).

Já Maradei (2017; p. 150) comenta em seu artigo que "as redes processam as contradições cotidianas, ou seja, o machismo, a sociedade patriarcal, a violência contra a mulher, o preconceito, mas também a tolerância, a cidadania, o empoderamento". Portanto, fica claro que a autora acredita que os atores sociais podem ser agentes de mudanças ou somente reproduzirem valores presentes na sociedade. No caso do Bahia, a comunicação apostou em cinco canais para disseminar seus novos interesses e valores a serem propagados para os stakeholders: Facebook, Instagram, Youtube, LinkedIn e Twitter. 


\section{TWITTER DO ESPORTE CLUBE BAHIA}

O Esporte Clube Bahia tem a $15^{\mathrm{a}}$ maior presença digital entre os clubes brasileiros, com aproximadamente 3.1 milhões de pessoas nas quatro principais redes sociais. A página no Twitter existe desde meados de abril de 2009 e tem cerca de 1.4 milhão de seguidores, número que representa 45,16\% da base total - segundo levantamento apresentado pelo IBOPE Repucom, em julho de 2019. O perfil é o principal canal de interação do clube com os stakeholders, atuando como fonte oficial de comunicação sobre o dia a dia, desde as categorias de base até a equipe profissional, e divulgação de ações, além de esclarecer as dúvidas mais frequentes do público.

Criado em 2006, o Twitter funciona como um microblogging, devido a produção simplificada de conteúdo e atualização frequente (SANTORO; SOUZA, 2008). Por conta da instantaneidade, amplo alcance e baixo custo, tornou-se um aliado na divulgação e propagação de conteúdo, sendo uma eficiente ferramenta no plano de comunicação das principais marcas. As mensagens, conhecidas como tweets, são limitadas a 280 caracteres, podendo ser publicada com foto, vídeo, link e enquete, seja pelo mobile, tablet ou desktop.

Através desta rede, o Bahia tem evidenciado seus valores, fomentado debates no espaço virtual e, consequentemente, gerado mídia espontânea a partir da interação e participação de outros indivíduos. Como relembra Torres (2009, p.113), “[...] sites na internet que permitem a criação e o compartilhamento de informações e conteúdos pelas pessoas e para pessoas, nas quais o consumidor é o mesmo tempo produtor e o consumidor da informação".

\section{ANÁLISE DE DADOS DO TWITTER}

Desde janeiro de 2019, a agremiação utiliza a conta @ecbahia para expor diversas questões inclusas na agenda social contemporânea, de maneira mais contínua e contundente, indo além das demarcações do campo de futebol. Foram realizadas as campanhas do Dia Nacional da Visibilidade Trans, no qual o clube lançou um manifesto e passou a adotar o nome social em todos os procedimentos administrativos; 'Ser diferente é normal', realizada em parceria com o Conselho Municipal dos Direitos das Pessoas com Deficiência; o 'Bahia da Massa', plano de sócio-torcedor com preços populares para pessoas carentes e com renda inferior a R\$ 1.500 ; 'Não há impedimento', que abraçou a pluralidade da torcida, lançada no Dia Internacional de Combate 
à LGBTfobia; o 'Me Deixe Torcer', um site para torcedoras tirarem dúvidas e realizarem denúncias em casos de assédio dentro do estádio; Dia da Mulher, que ressaltou a luta contra o assédio e promoveu o trabalho realizado pelas Filhas de Gandhy, grupo afro que acolhe vítimas de violência doméstica; Ronda Maria da Penha, que buscou garantir a segurança das torcedoras na Arena Fonte Nova; entre outras.

De acordo com Cruz e Martinelli (2007), a associação da marca a causas sociais é uma estratégia que pode gerar reputação positiva perante ao público. Norteada por essa constatação, este trabalho fez um comparativo do engajamento nos seis primeiros meses de 2018, período sem ações afirmativas, com o mesmo período de 2019, a fim de compreender se geraram impactos relevantes.

A primeira métrica analisada por esta pesquisa foi o número de impressões da página, que representa quantas vezes as publicações foram exibidas para os usuários. De antemão, se faz necessário afirmar que as métricas não foram frutos somente do engajamento social, mas inegavelmente influenciam nos números finais. De acordo com o Analitycs, recurso da rede social voltada para gerenciamento de contas, a página alcançou 53.3 milhões de impressões contra 71.2 milhões, respectivamente, crescimento de aproximadamente 33,6\%. Entretanto, é importante salientar que é possível que um mesmo indivíduo tenha sido contabilizado diversas vezes. Por ser referente apenas à visualização, a impressão não traz muitos insumos para compreender, de fato, a efetividade das publicações, porém não deve ser descartada, já que pode representar indiretamente o alcance. Os dados estão disponíveis no Gráfico 1.

Gráfico 1 - Comparativo de impressões da conta @ecbahia

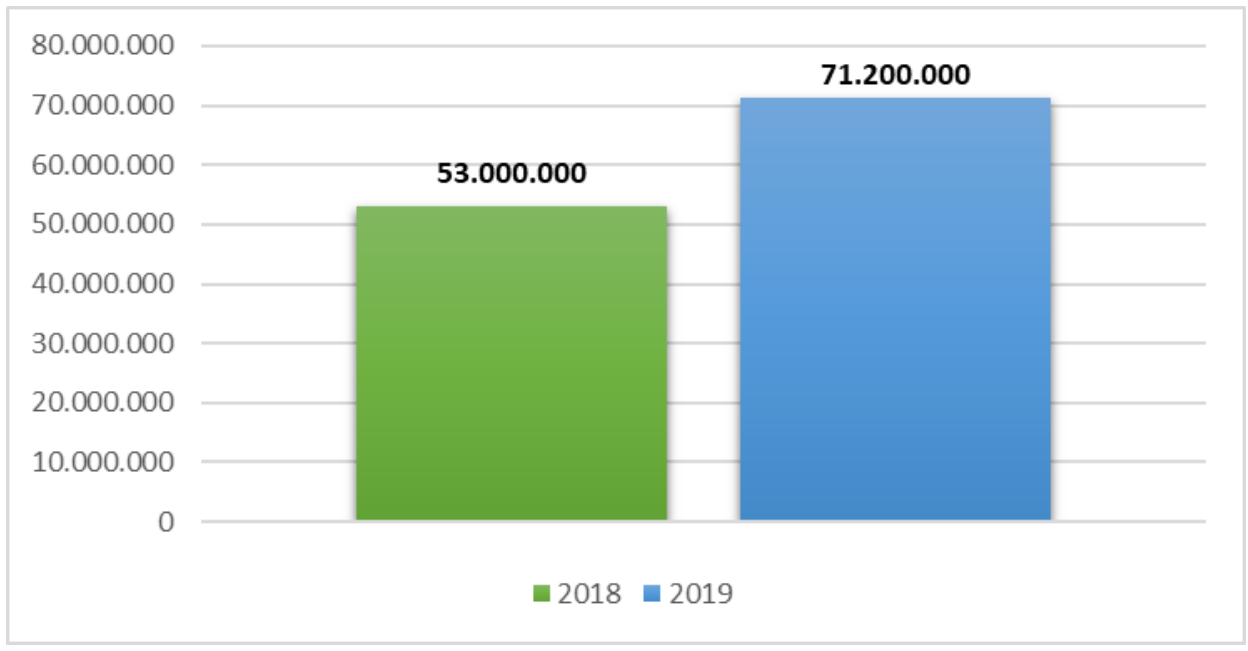

Fonte: Relatório extraído no Twitter Analitycs, fornecido pelo clube. 
O segundo $k p i^{4}$ analisado foi o retweet. Essa função contribui com a disseminação de informação e determina indiretamente o poder de persuasão de cada canal. Os dados apontados na ferramenta mostram que os $r t s$, como popularmente é conhecido entre os usuários, saltou de 119 mil para 137.9 mil, como demonstra o Gráfico 2. Houve aumento de 15,9\%.

Gráfico 2 - Comparativo de retweets da conta @ecbahia

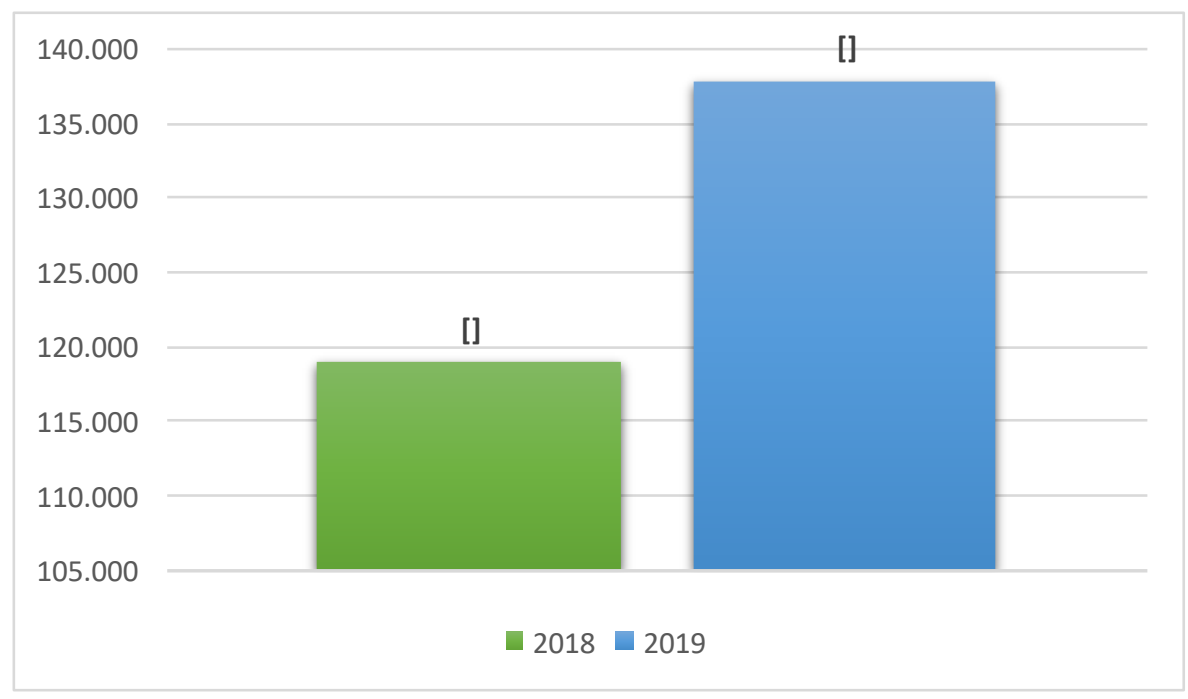

Fonte: Relatório extraído no Twitter Analitycs, fornecido pelo clube.

A curtida foi outro índice avaliado na mensuração do impacto das campanhas, já que é a percepção da base de fãs sobre cada publicação. Durante o primeiro semestre de 2018, foram 676.7 mil contra 1.390.400 milhão em 2019. O kpi, que pode ser conferido no Gráfico 3, apresentou aumento de aproximadamente 105\%. O levantamento também registrou elevação nos cliques no link, ação referente ao número de vezes que usuários clicaram nos endereços virtuais compartilhados junto com os tweets. Como apresenta o Gráfico 4, foram 98.5 mil cliques contra 146.1 mil (+48,32\%), respectivamente.

\footnotetext{
${ }^{4}$ Sigla em inglês para Key Performance Indicator, ou Indicadores-Chave de Desempenho. São métricas definidas como essenciais na gestão de mídias sociais, como por exemplo compartilhamento, curtir, alcance, etc.
} 
Gráfico 3 - Comparativo de curtidas da conta @ecbahia

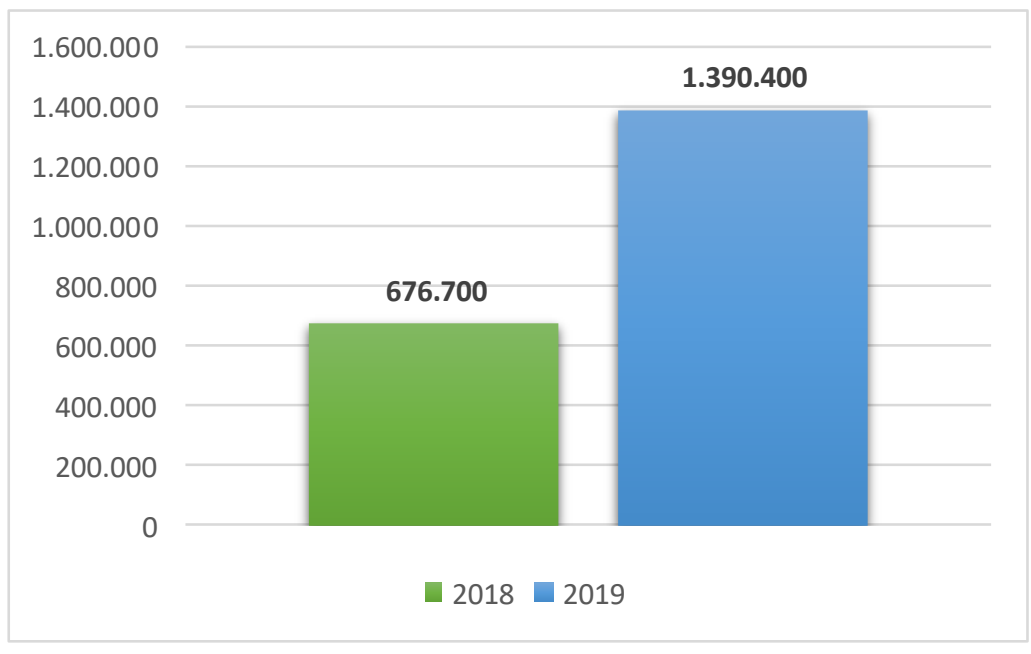

Fonte: Relatório extraído no Twitter Analitycs, fornecido pelo clube.

Gráfico 4 - Comparativo de cliques no link da conta @ecbahia

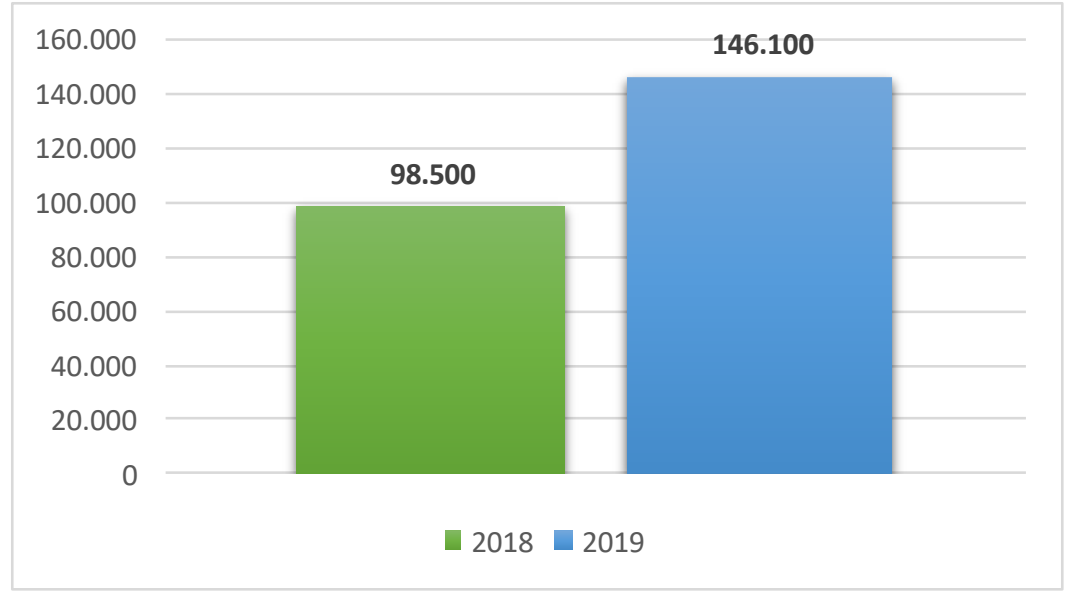

Fonte: Relatório extraído no Twitter Analitycs, fornecido pelo clube.

Outros dois fatores foram considerados por esta pesquisa: respostas e audiência. De acordo com o Analitycs, foram 40.8 mil interações entre janeiro e junho de 2018, enquanto, em 2019, houve 78.8 mil. Elevação significativa de $73.52 \%$ no comparativo, apresentado no Gráfico 5. Já o comportamento da audiência do perfil foi na contramão dos resultados anteriormente apresentados. Foram 94.025 novos seguidores no primeiro recorte, ampliando de 1.290 milhão para 1.384 milhão, contra, aproximadamente, 26 mil pessoas, salto de 1.380 milhão para 1.402 milhão. Contudo, é importante ressaltar que, segundo o Canal Tech, a plataforma registrou $11 \%$ de crescimento de usuários por dia, durante os primeiros meses de 2018. 
Gráfico 5 - Comparativo de respostas da conta @ecbahia

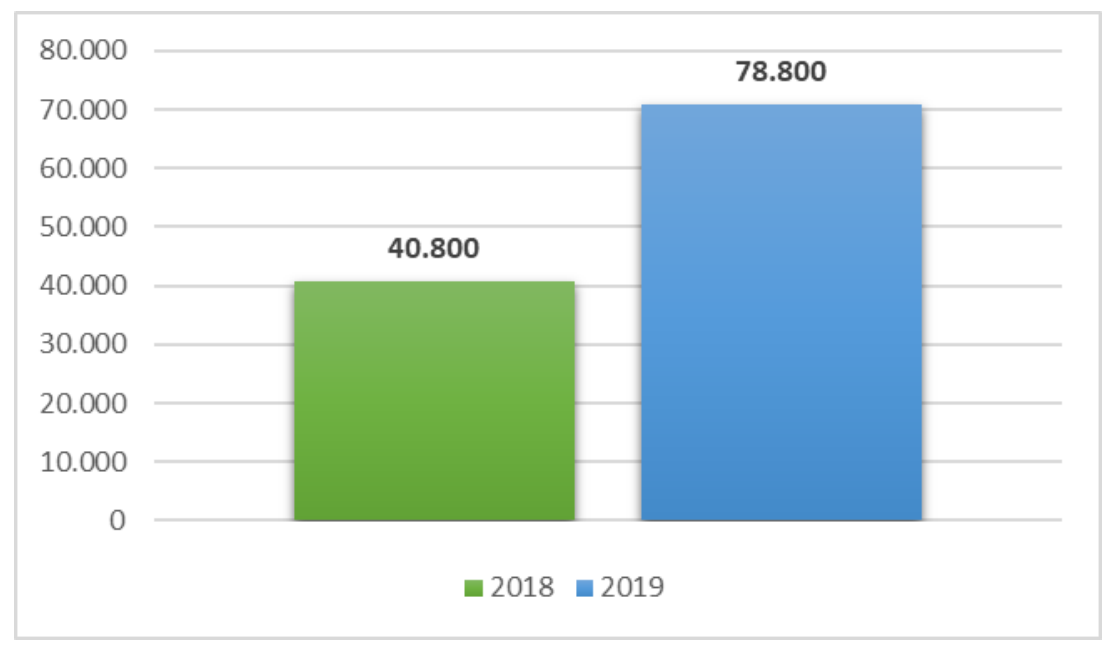

Fonte: Relatório extraído no Twitter Analitycs, fornecido pelo clube.

Ademais, notou-se, como supracitado, que houve maior concentração de ações afirmativas no primeiro trimestre de 2019. Diante disso, também foi avaliado se a maior quantidade de campanhas refletiu nos números de engajamento entre os recortes temporais. Os dados revelaram, como evidencia o Gráfico 6, que foram 29.7 milhões de impressões, entre $1^{\circ}$ de janeiro e 31 de março, contra 41.5 milhões nos meses posteriores, diferença significativa de 19.8 milhões $(39,73 \%)$. Os retweets também seguiu a tendência e foram ampliados durante recorte, como mostra o Gráfico 7: crescimento de 74,70\%. Foram 50.2 mil entre os primeiros meses e 87.7 mil na segunda parte, respectivamente.

Gráfico 6 - Comparativo de engajamento nos primeiros trimestres de 2019

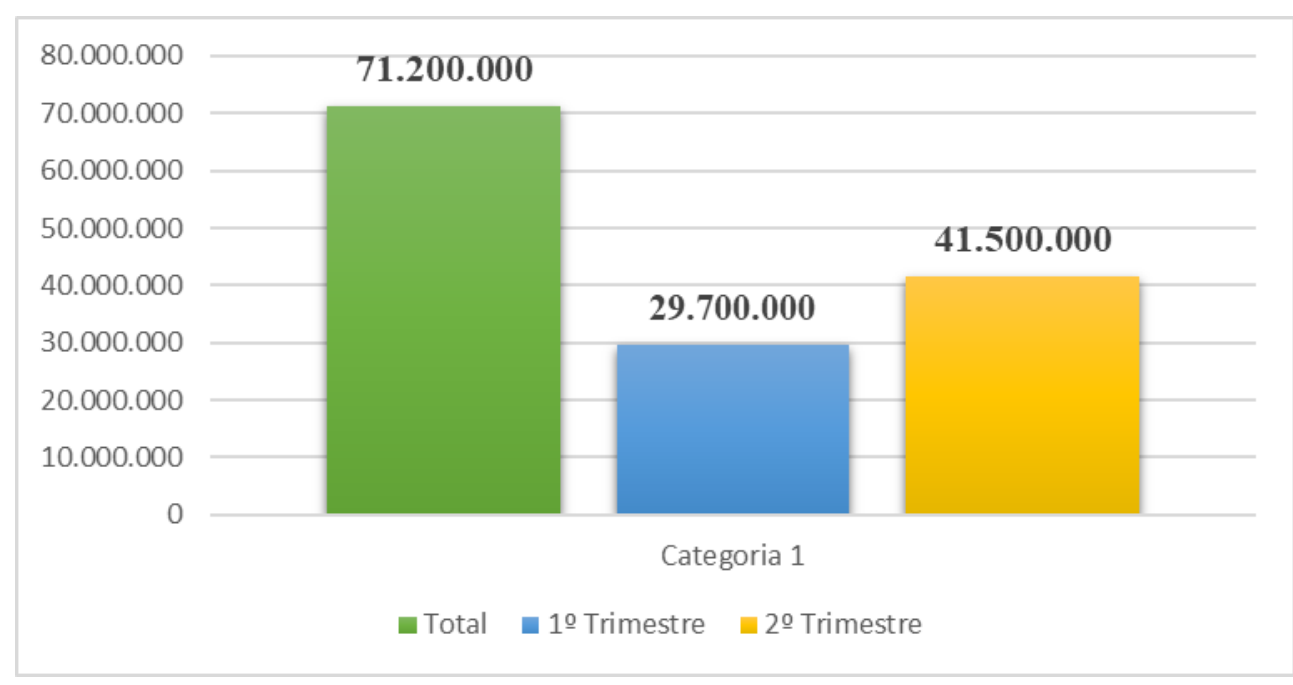

Fonte: Relatório extraído no Twitter Analitycs, fornecido pelo clube. 
PROGRAMA DE PÓS-GRADUAÇÃO EM COMUNICAÇÃO DA UNIVERSIDADE FEDERAL DE SANTA MARIA

Gráfico 7 - Comparativo de retweets nos primeiros trimestres de 2019

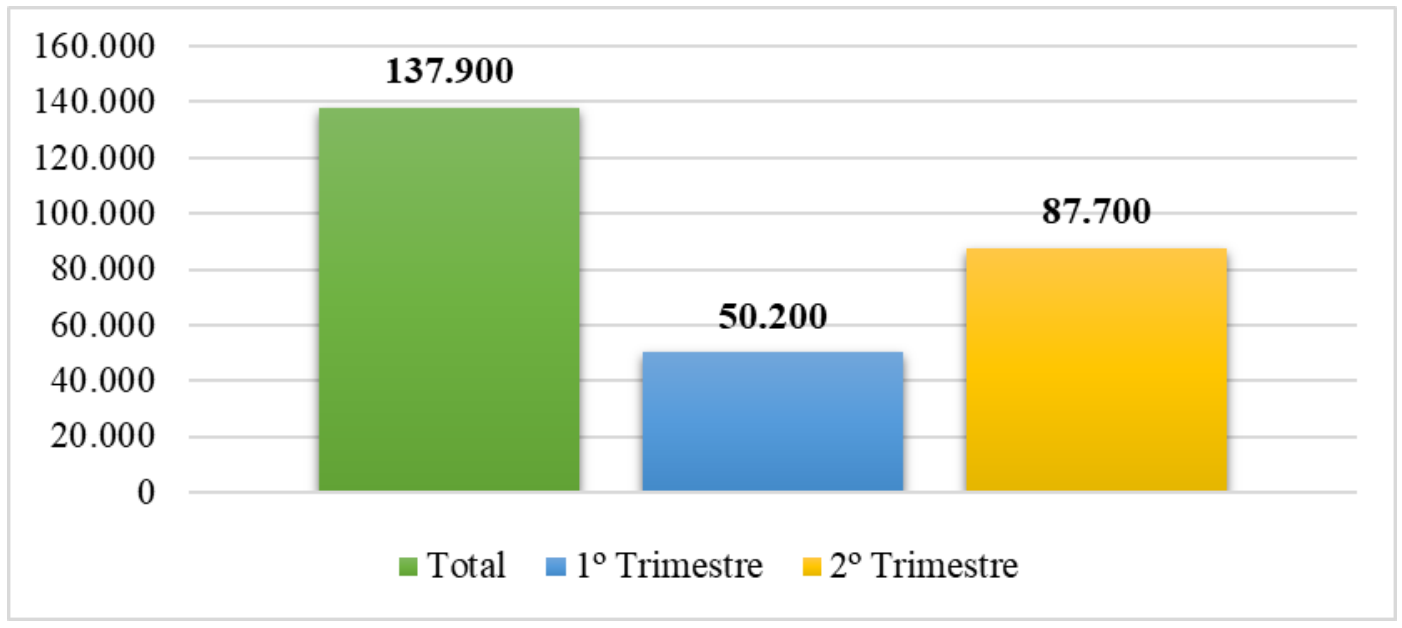

Fonte: Relatório extraído no Twitter Analitycs, fornecido pelo clube.

Como anteriormente referido, o “@ecbahia” conseguiu, aproximadamente, 1.4 milhão de favoritos durante os seis primeiros meses de 2019. Entretanto, os dados elucidaram que os números cresceram gradativamente a partir da criação e divulgação de políticas de reparação e conscientização do público. O Gráfico 8 mostra que foram computadas 543.9 mil curtidas nos três primeiros meses, já o segundo trimestre teve 846.5 mil interações desse tipo, taxa de aumento de 55,63\%. Os cliques no link e respostas também seguiram o padrão de crescimento: 40,29\% e 3,93\%, respectivamente. Enquanto a primeira métrica, divulgada no gráfico 9, contou com 146,1 mil em todo semestre, com 60.8 mil entre janeiro e março; e 85.3 mil entre abril e junho; a segunda subiu de 35.7 mil para 37.1 mil. O índice foi representado no Gráfico 10.

Gráfico 8 - Comparativo de curtidas nos primeiros trimestres de 2019

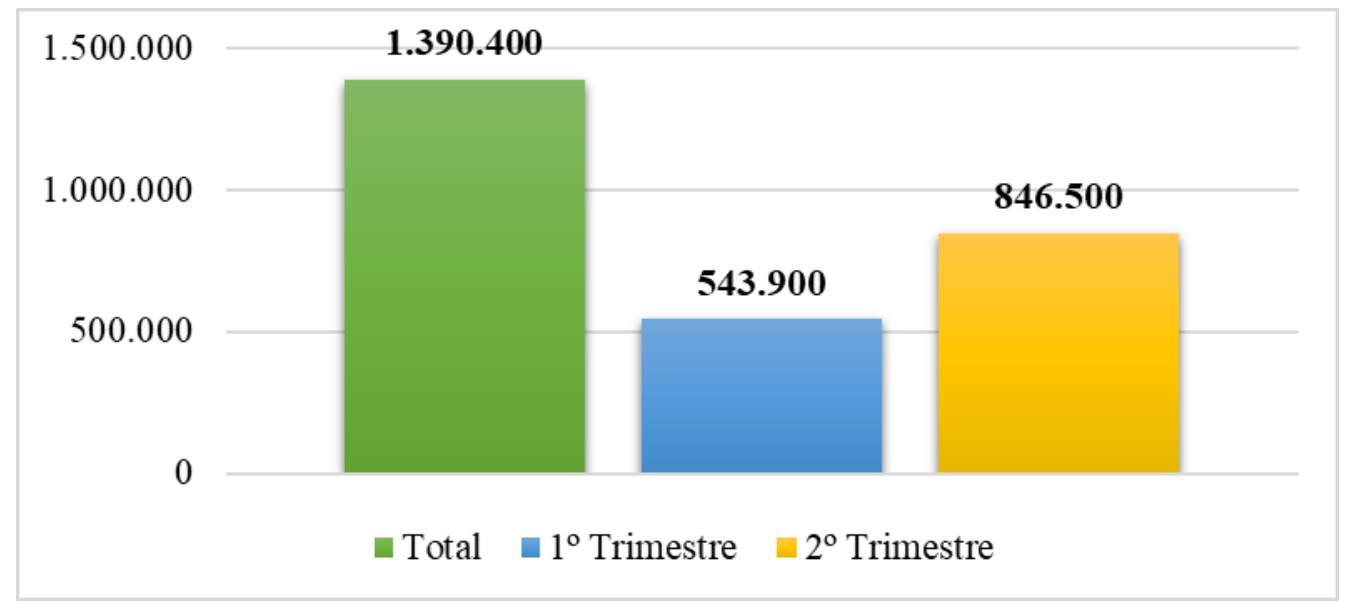

Fonte: Relatório extraído no Twitter Analitycs, fornecido pelo clube. 
PROGRAMA DE PÓS-GRADUAÇÃO EM COMUNICAÇÃO DA UNIVERSIDADE FEDERAL DE SANTA MARIA

Gráfico 9- Comparativo de cliques no link nos primeiros trimestres de 2019

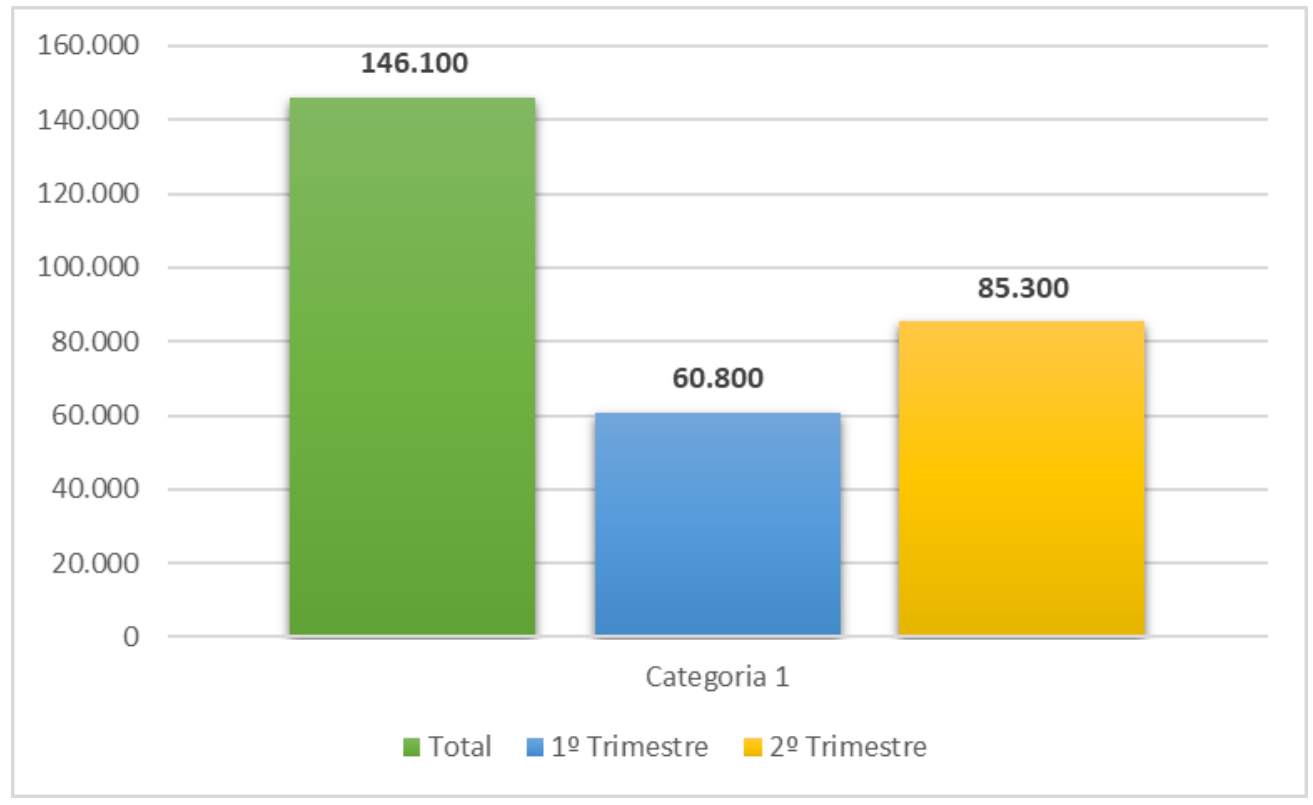

Fonte: Relatório extraído no Twitter Analitycs, fornecido pelo clube.

Gráfico 10 - Comparativo de respostas nos primeiros trimestres de 2019

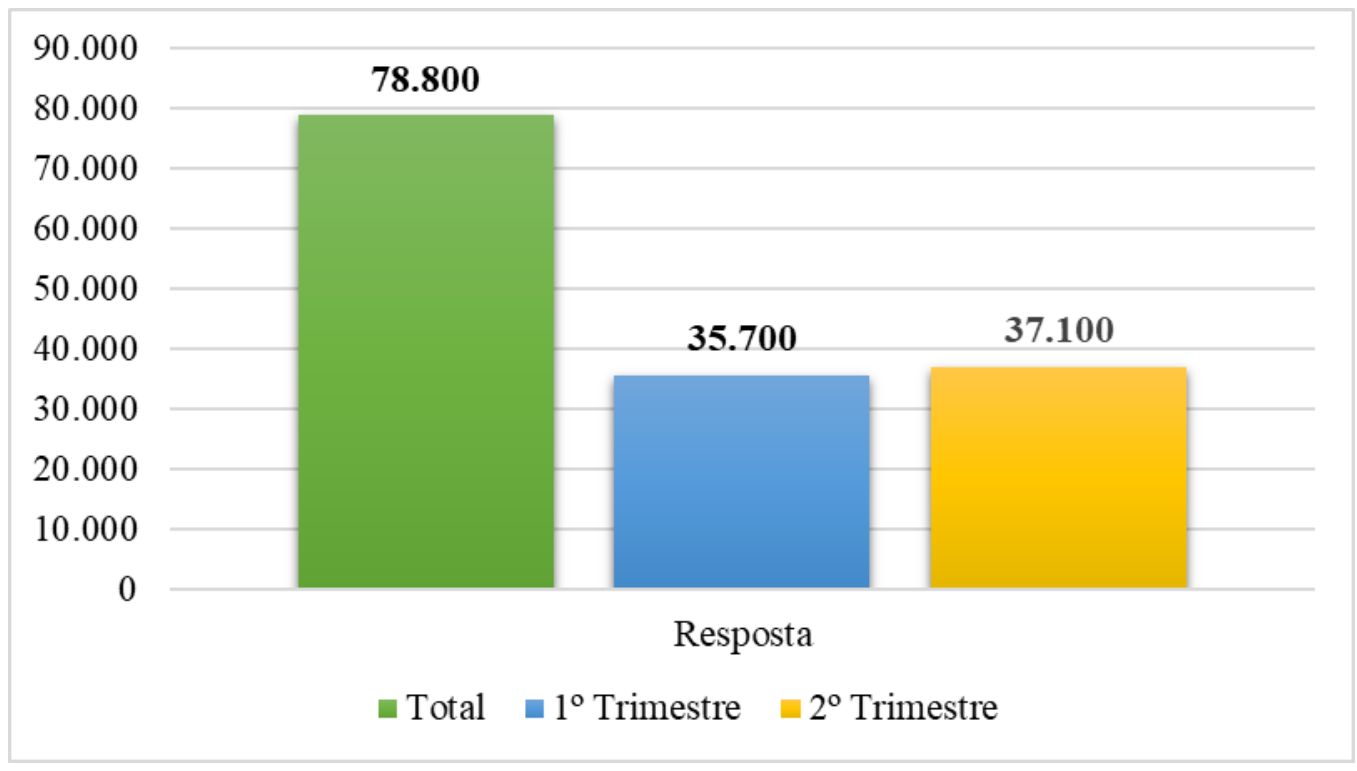

Fonte: Relatório Twitter Analitycs, fornecido pelo clube

Ademais, se fez necessário verificar como o número de seguidores da página reagiu durante o desenvolvimento das ações afirmativas. Em seis meses, a base do “@ecbahia" cresceu de 1.376.540 milhão para 1.402.905 milhão, aumento de aproximadamente 26 mil pessoas, segundo dados gerados pelo próprio clube. Entretanto, o recorte entre janeiro (4.139), 
fevereiro (2.688) e março (3.654) não teve tanto sucesso quanto abril (5.073), maio (6.283) e junho (4.182). Foram 10.481 novos fãs contra 15.538, respectivamente.

\section{FORMULÁRIO DE TORCEDORES}

No estudo, foram obtidos 624 questionários respondidos, através da ferramenta do Google, compartilhado exclusivamente pela conta de um dos pesquisadores no Twitter, e a descrição das características sociodemográficas foram relatadas na Tabela 1. O perfil apresentou predominância de pessoas jovens do sexo masculino, com faixa de renda entre $1 \mathrm{e}$ 3 salários mínimos (R\$ 998 a R\$2.994) e idade entre 18 e 25 anos.

Tabela 1 - Dados socioeconômicos de formulário aplicado no Google Forms

\begin{tabular}{|c|c|c|c|}
\hline Variáveis & Categorias & Frequência (n) & $\begin{array}{c}\text { Porcentagem } \\
(\%)\end{array}$ \\
\hline \multirow[t]{2}{*}{ Sexo } & Masculino & 506 & 81,1 \\
\hline & Feminino & 118 & 18,9 \\
\hline \multirow[t]{6}{*}{ Idade } & Menos de 18 & 19 & 3 \\
\hline & De 18 a 25 anos & 197 & 31,6 \\
\hline & De 26 a 31 anos & 151 & 24,2 \\
\hline & De 32 a 40 anos & 156 & 25 \\
\hline & De 41 a 50 anos & 59 & 9,5 \\
\hline & Mais de 51 anos & 42 & 6,7 \\
\hline
\end{tabular}




\begin{tabular}{|c|c|c|c|}
\hline \multirow[t]{7}{*}{ Renda } & Até 1 salário mínimo (R $\$ 998)$ & 112 & 17,9 \\
\hline & $\begin{array}{l}\text { De } 1 \text { a } 3 \text { salários mínimos (de } \\
\text { R\$998,01 até R\$ 2.994) }\end{array}$ & 201 & 32,2 \\
\hline & $\begin{array}{l}\text { De } 3 \text { a } 6 \text { salários mínimos (de } \\
\text { R } \$ 2.994,01 \text { até } \mathrm{R} \$ 5.988 \text { ) }\end{array}$ & 140 & 22,4 \\
\hline & $\begin{array}{l}\text { De } 6 \text { a } 9 \text { salários mínimos } \\
\text { (de5.988,01 até } \mathrm{R} \$ 8.982 \text { ) }\end{array}$ & 56 & 9 \\
\hline & $\begin{array}{l}\text { De } 9 \text { a } 12 \text { salários mínimos (de } \\
\mathrm{R} \$ 8.982,01 \text { até } \mathrm{R} \$ 11.976 \text { ) }\end{array}$ & 51 & 8,2 \\
\hline & $\begin{array}{l}\text { De } 12 \text { a } 15 \text { salários mínimos (de } \\
\mathrm{R} \$ 11.976 \text { até } \mathrm{R} \$ 14.970)\end{array}$ & 21 & 3,4 \\
\hline & $\begin{array}{l}\text { Mais de } 15 \text { salários mínimos } \\
\text { (acima de } 14.970 \text { ) }\end{array}$ & 43 & 6,9 \\
\hline
\end{tabular}

Fonte: Dados obtidos através de formulário aplicado na internet.

Uma vez estabelecido o perfil do público que respondeu ao formulário, levantou-se que 91,8\% (573) foi formado por torcedores do Esporte Clube Bahia e que 95,7\% (597) afirmaram que os clubes devem discutir problemas efervescentes na sociedade, como apontam os Gráficos 11 e 12. 
Gráfico 11 - Tipo de Relacionamento com o clube (\%)

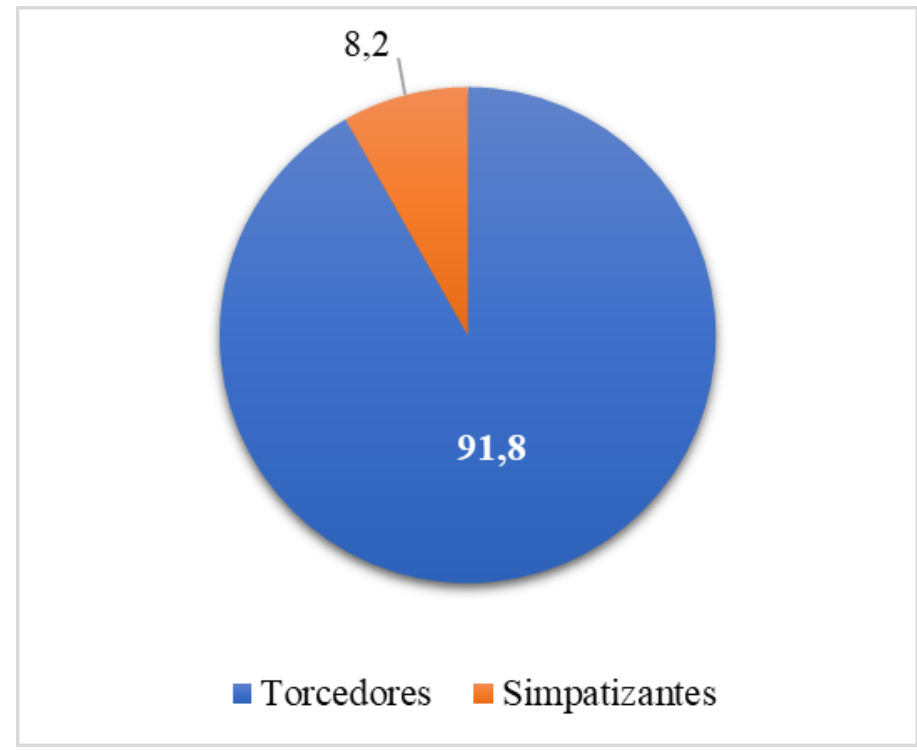

Fonte: Dados obtidos através de formulário aplicado na internet.

Gráfico 12 - Participação dos clubes em debates sociais (\%)

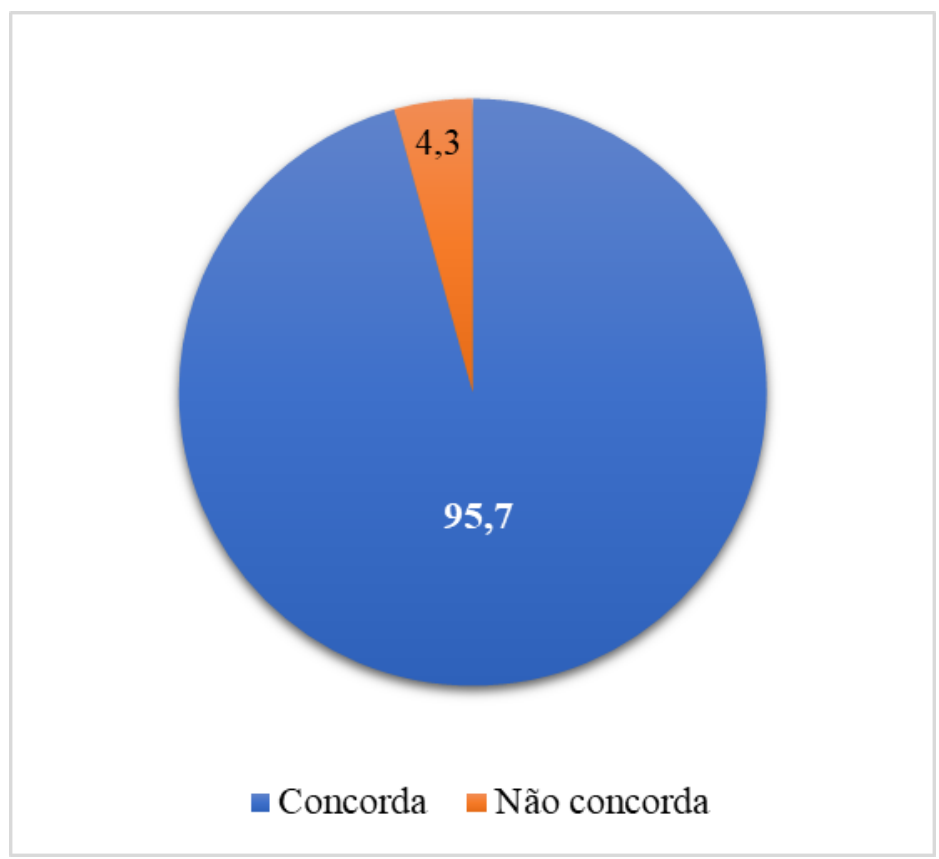

Fonte: Dados obtidos através de formulário aplicado na internet.

Ademais, verificou-se que 96,2\% (600) consideram as ações afirmativas aplicadas pelo Bahia como algo positivo, 95,7\% (597) aprovam a postura combativa acerca de temas presentes na sociedade e 95,5\% (596) acreditma que as campanhas realizadas levaram a algum tipo de reflexão, como está evidenciado nos Gráficos 13, 14 e 15, respectivamente. 


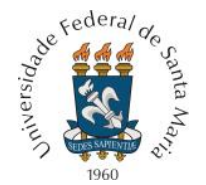

PROGRAMA DE PÓS-GRADUAÇÃO EM COMUNICAÇÃO DA UNIVERSIDADE FEDERAL DE SANTA MARIA

Gráfico 13 - Avaliação das ações afirmativas (\%)

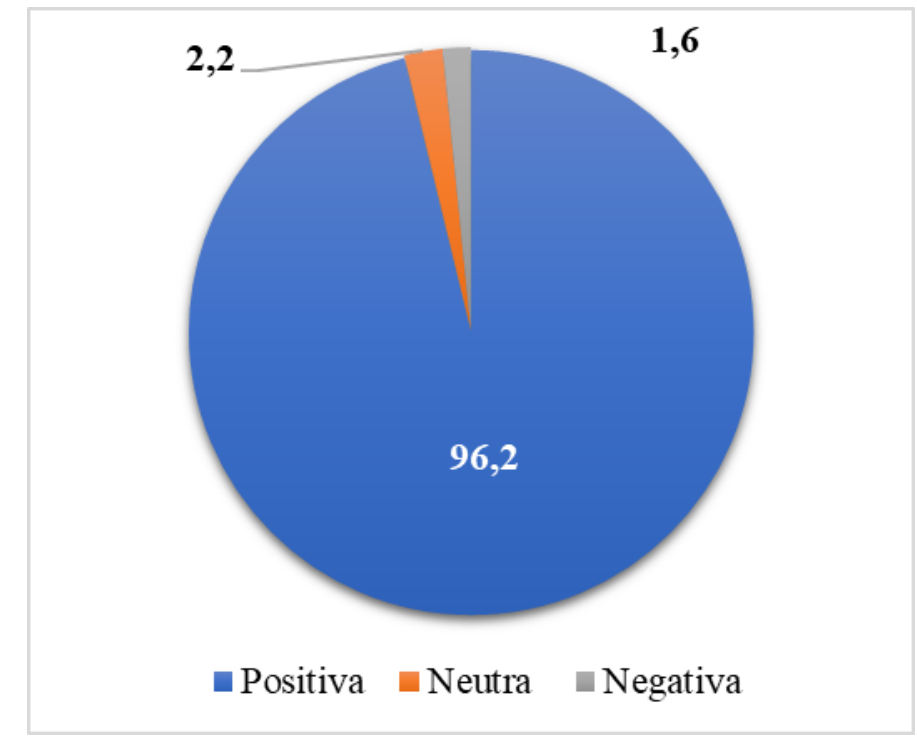

Fonte: Dados obtidos através de formulário aplicado na internet.

Gráfico 14 - Opinião sobre a imagem do Bahia após ações afirmativas (\%)

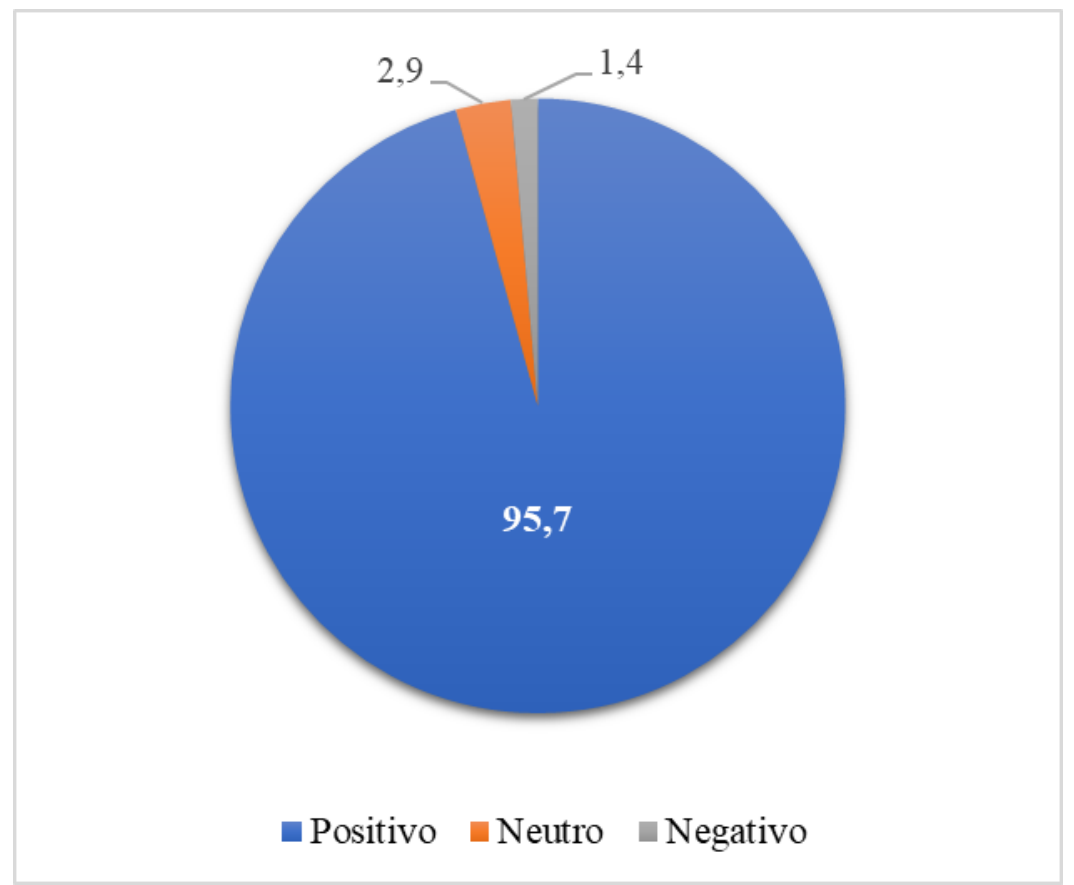

Fonte: Dados obtidos através de formulário aplicado na internet. 
Gráfico 15 - As ações proporcionou algum tipo de reflexão (\%)

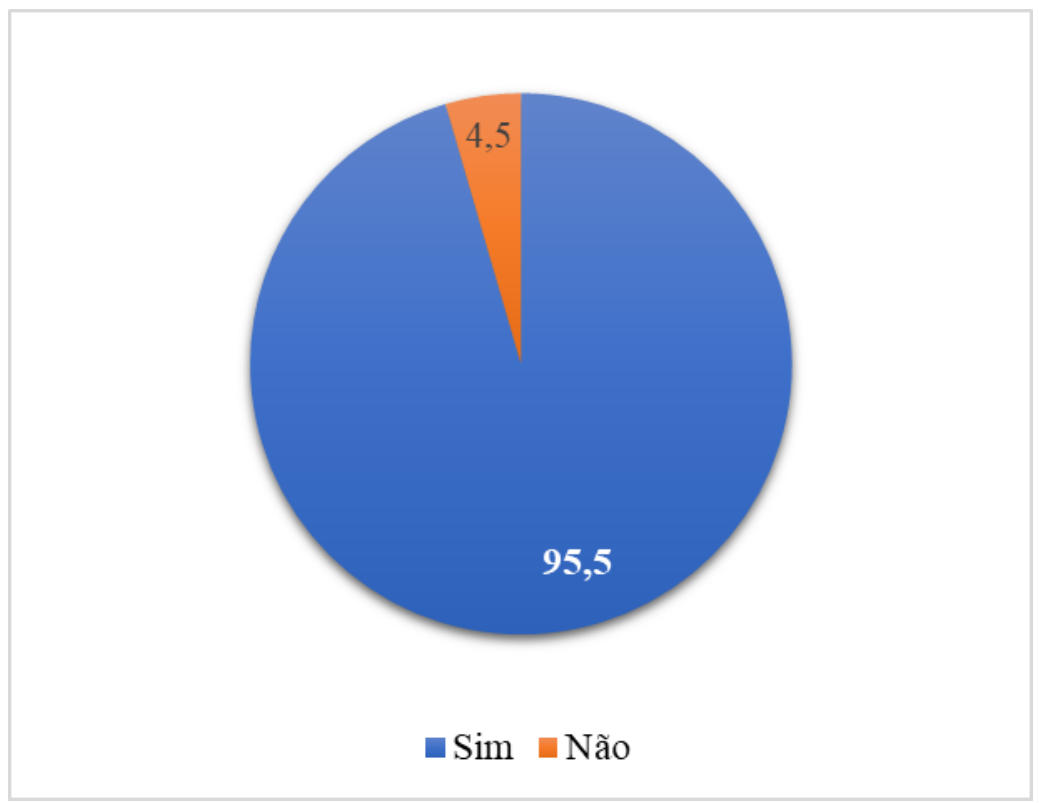

Fonte: Dados obtidos através de formulário aplicado na internet.

Verificou-se no Gráfico 16 que racismo (60\%), assédio (57,7\%) e machismo (56,1\%) foram as temáticas mais escolhidas por torcedores para serem mais exploradas pela agremiação nas próximas ações. Diante das respostas obtidas, notou-se que os stakeholders estão cada vez mais exigentes em relação ao modo como a marca se posiciona diante das questões contemporâneas. Como relembra Margarida Kunsch (2014):

As ações isoladas de comunicação de marketing e de relações públicas são insuficientes para fazer frente aos novos mercados competitivos e para os relacionamentos com os públicos e ou interlocutores dos diversos segmentos. Estes são cada vez mais exigentes e cobram das organizações responsabilidade social, atitudes transparentes, comportamentos éticos, respeito à preservação do planeta etc., graças a uma sociedade mais consciente e uma opinião pública sempre vigilante (2014; p. 41) 
Gráfico 16 - Temas que poderiam ser mais abordados

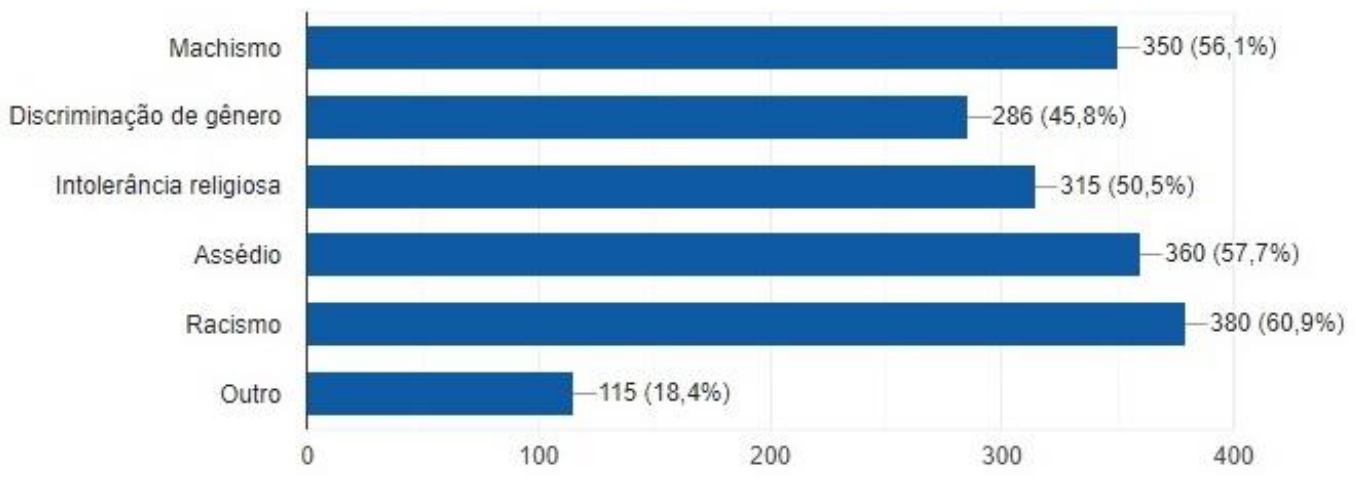

Fonte: Dados obtidos através de formulário aplicado na internet.

Por fim, foram analisadas as respostas acerca dos motivos que levaram cada entrevistado a classificar o impacto das ações como positiva, negativa ou neutra, a fim de compreender como uma amostra considerável da torcida enxergou, detalhadamente, a postura combativa da agremiação. Em sua maioria, foi exposto que esse tipo de discussão é interessante, pois fomentou debate sociais essenciais na formação cidadã, capaz de derrubar qualquer forma de preconceito, além de gerar retorno mercadológico.

Vivemos um momento de muitas discussões sociais, assumir o protagonismo nesses assuntos é sair na frente no ponto vista moral e consequentemente mercadológico. As posições adotadas pelo Bahia são indiferentes aos preconceituosos e muito positivas aos olhos dos que sofrem e/ou lutam contra as injustiças sociais. O clube só tem a ganhar. (Homem, de 26 a 31 anos, de 3 a 6 salários mínimos)

Por alcançar diversas camadas sociais e intelectuais, os clubes apresentam importante papel da disseminação de informações, principalmente relacionadas a construção social. Sendo assim, a abordagem desses temas coloca os clubes em posição de destaque, gerando impacto positivo. (Mulher, de 18 a 25 anos, de 9 a 12 salários mínimos)

Preciso colaborar com a desconstrução de uma sociedade que ainda cultiva muitos preconceitos como a nossa. As incursões do time nesse sentido ajudam a mostrar que todos precisam participar desse processo. (Masculino, de 32 a 40 anos, de 1 a 3 salários mínimos)

Apesar do interesse em trabalhar além dos aspectos futebolísticos, o Bahia também foi alvo das críticas de uma fatia de seguidores que não concordou com esse tipo de postura, mesmo que em número bastante inferior, em comparação aos comentários positivos. Como 
afirma Margarida Kunsch (2014), as marcas devem compreender que as mensagens discursivas são passíveis de serem recebidas de diversas formas, graças à capacidade individual e cognitiva e o contexto de cada receptor. Portanto, em meio aos elogios, também há comentários negativos, como "soa demagógico e politicamente correto. Posts em redes sociais são feitos por diversas empresas e isso não muda a realidade em que vivemos" (homem, de 18 a 25 anos, de 9 a 12 salários mínimos), e "o presidente do Bahia está utilizando do clube para divulgar ideologias a favor do seu viés político, para em breve utilizar disso para se candidatar a um cargo político!" (homem, de 26 a 31 anos, de 1 a 3 salários mínimos). Ademais, também foram registradas opiniões neutras:

Os dois, por isso neutro. Vivemos em um momento em que no mundo todo essas questões estão sendo discutidas, posturas estão sendo mudadas. Entretanto, o conservadorismo e seus correlatos tem se mostrado com mais força. Nesse sentido, penso que tem a postura do Bahia tem lado positivo para aqueles que se permitem discutir tais assuntos, mas negativo para os que assumem posturas preconceituosas etc. (Mulher, de 26 a 31 anos, de 3 a 6 salários mínimos)

Neutro, pois gera uma imagem positiva diante daqueles que também combatem esses temas, porém negativo diante daqueles que são preconceituosos. O balanço final é positivo, é necessário o clube se posicionar, mas é necessário levar em conta sim o arranhão que a imagem do clube sofre diante dos preconceituosos que, mal ou bem, também são consumidores do produto futebol - em alguns casos, até maioria. (Homem, de 18 a 25 anos, de 1 a 3 salários mínimos)

Isso se deu por conta do novo momento da sociedade, onde os indivíduos estão cada vez mais conscientes e solidários com os próximos, exigindo uma postura inovadora das empresas, seja no campo social ou ambiental (Kunsch, 2014). Portanto, “todas essas transformações alteraram por completo o comportamento institucional das organizações e a comunicação passou a ser considerada de outra maneira” (KUNSCH, 2014, p. 41)

\section{CONCLUSÃO}

Fenômeno sociocultural capaz de superar barreiras, o futebol foi tratado durante anos como mais uma ferramenta alienante da indústria cultural, sendo responsável por desviar a atenção dos indivíduos de fatos relevantes do dia a dia, como a má prestação de serviços ligados à saúde e educação, desemprego etc. No Brasil, a omissão dos clubes em momentos 
importantes ao longo da história e a apropriação da Seleção Brasileira por parte do Governo Federal no período da Ditadura Militar ratificou a imagem negativa do esporte. Entretanto, o quadro vem mudando gradativamente com o passar dos anos, já que as agremiações compreenderam o papel relevante que podem exercer na formação da sociedade.

Apontado como referência no país e voz dissonante, o Esporte Clube Bahia tem utilizado a página oficial no Twitter (@ecbahia) de maneira assertiva para fomentar o debate e a reflexão de questões sociais e humanitárias, que estão em voga em nossa sociedade. Notouse, a partir dos dados coletados e analisados através do Twitter Analitycs, que as ações afirmativas, mesmo que de forma indireta, resultou em efeitos positivos para o perfil, que foram comprovados através da taxa de crescimento dos números de impressões $(33,6 \%)$, retweets $(15,9 \%)$, cliques no link $(48,32 \%)$, curtidas (105\%) e respostas $(73.52 \%)$, evidenciados através do comparativo entre os seis primeiros meses de 2019. Portanto, destacou-se a eficiência da mídia como um canal direto com o torcedor.

Observou-se que, em uma dimensão qualitativa, o cenário político do país e a eventual candidatura de Guilherme Bellintani, atual presidente do Bahia, à Prefeitura de Salvador, por um suposto partido considerado ideologicamente como de esquerda, não gerou altos índices de reprovação e/ou questionamento. Em números totais, 96,2\% se mostrou satisfeito com o engajamento social, 95,7\% aprovou a postura e 95,5\% entendeu que as campanhas podem contribuir com as mudanças na sociedade. O retorno positivo para imagem do clube se deu porque a responsabilidade social, sustentabilidade e igualdade de gênero, raça, entre outros tipos de relações, são cada vez mais exigidas pelos stakeholder, já que as empresas, inclusive as agremiações de futebol, "estão sendo chamadas para um novo questionamento do seu papel no sistema social global" (KUNSCH, 2014; p. 40).

Assim, este trabalho compreendeu que a comunicação do Esporte Clube Bahia realizou, até este momento, um trabalho significativo no que se refere à produção de conteúdo e integração com a política humanitária que norteia a instituição, precisando apenas de pequenas adequações para alavancar, indiretamente, os resultados financeiros. Nesse sentido, também é importante reforçar a importância do clube utilizar melhor os dados gerados pela rede social para planejar o calendário de postagens, ampliando os índices de engajamento.

Por fim, acredita-se que os dados gerados por este artigo podem ser explorados para o projeto de mestrado do autor e/ou servir como inspiração para estudos sobre mídias sociais no âmbito do futebol. Da mesma forma, entende-se que podem surgir novas análises acerca das ações afirmativas produzidas pelo Esporte Clube Bahia e o impacto na sociedade. 


\section{REFERÊNCIAS}

BELLINTANI, Guilherme. Bahia apoia causas sociais em busca de diversidade na sua torcida. Folha de São Paulo: maio, 2019. Entrevista concedida à João Gabriel. Disponível em: <https://www1.folha.uol.com.br/esporte/2019/05/bahia-apoia-causas-sociais-em-busca-dediversidade-na-sua-torcida.shtml>. Acesso em: 21 de junho de 2019.

CAMPOS, Mariane Motta; COIMBRA, Mayra Regina; OLIVEIRA, Luiz Ademir. A construção da imagem de Dilma Rousseff e de seu governo no processo de Impeachment: uma análise dos pronunciamentos políticos. e-Com, v. 11, n. 1, p. 6-31, 2018. Disponível em: <http://unifatea.com.br/seer3/index.php/ECCOM/article/view/1065/992>. Acesso em: 5 set. 2016

CASTELLS, Manuel. A Galáxia Internet: reflexões sobre a Internet, negócios e a sociedade. Zahar, 2003.

COLNAGO, Camila Khroling. Mídias e redes sociais digitais: conceitos e prá ticas. In BUENO, Wilson da Costa. Estratégias de comunicação nas mídias sociais. Barueri: Manoele, 2015. cap.1. p.322.

DOSSIÊ ESPORTE. Um estudo sobre o esporte na vida do brasileiro. Disponível em: <http://cev.org.br/arquivo/biblioteca/4018794.pdf >.Acesso em: 5 de setembro 2016.

EXTRA. 'Melhor Copa do Mundo da História' teve audiência recorde em 2018, diz Fifa. Disponível em: <https://extra.globo.com/esporte/melhor-copa-do-mundo-da-historia-teve-audiencia-recorde-em-2018diz-fifa-23321043.html>. Acesso em: 5 junho de 2019.

FRANCO JÚNIOR, Hilário. A dança dos deuses: futebol, sociedade, cultura. São Paulo: Companhia das Letras, 2007.

IBGE - Instituto Brasileiro de Geografia e Estatística. Pesquisa Nacional por Amostra de Domicílios - 2017. Rio de Janeiro: IBGE. Disponível em: <https://www.ibge.gov.br/estatisticas/sociais/trabalho/17270-pnadcontinua.html?edicao=20915\&t=resultados $>$ Acesso em: 27 de junho de 2019.

IBGE - Instituto Brasileiro de Geografia e Estatística. Estimativa de População Residente no Brasil e Unidades da Federação com Data de Referência em $1^{\circ}$ de Julho de 2019. Rio de Janeiro: IBGE. Disponível em:

<https://ftp.igbe.gov.br/Estimativas_de_População/Estimativas_2019/estimativa_dou_2019.pdf. Acesso em 14 de julho de 2021.

IPOBE REPUCOM. Ranking digital dos clubes brasileiros: dezembro 2018. Disponível em: <http://www.iboperepucom.com/br/rankings/ranking-digital-dos-clubes-brasileiros-jul2019/>. Acesso em: 5 de julho de 2019 .

KUNSCH, Margarida M. KrohliNg. Comunicação Organizacional: contextos, paradigmas e abrangência conceitual. Matrizes, v. 8, n. 2, p. 35-61, 2014.

LEANDRO, Paulo Roberto. Ba-Vi: da assistência à torcida: a metamorfose nas páginas esportivas. 2013. Acesso em: 24 de junho de 2019.

MARADEI A, SANTOS M. Violência contra as mulheres: o caso do estupro coletivo na esfera pública digital. Intercom - RBCC, 2017; 40 (2):143-168.

MURAD, Maurício. Práticas de violências e mortes no futebol brasileiro. Revista USP, São Paulo, n. 99, 2013 cap.1. p. 139-152. Disponível em: <

http://www.periodicos.usp.br/revusp/article/view/76312/80030>. Acesso em: 29 de julho de 2019. 
MURAD, Maurício. Violências e mortes no futebol brasileiro Reflexões, investigações, proposições. Revista Portuguesa de Ciências do Desporto, v. 13, n. 1, 2013. Acesso em: 24 de junho de 2019.

RECUERO, R. Redes Sociais na Internet. Porto Alegre: Sulina (Coleção Cibercultura), 2009.

RECUERO, R. A rede é a mensagem: Efeitos da Difusão de Informações nos Sites de Rede Social. In: Eduardo Vizer. (Org.). Lo que Mcluhan no previó. 1ed.Buenos Aires: Editorial La Crujía, 2012, v. 1, p. 205-223. Acesso em 13 de abril de 2019.

SANTORO, G.; SOUZA, M. A. Blogs corporativos: uma análise dos blogs mantidos por sete das maiores empresas do Brasil. In: SEMINÁRIOS EM ADMINISTRAÇÃO, 11., 2008, São Paulo. Anais... São Paulo, 2008.

TORRES, Cláudio. A Bíblia do Marketing Digital. 2 ed. São Paulo. Novatec 2009.

Um em cada cinco brasileiros torce para o Flamengo, aponta Datafolha. Folha de S.Paulo, São Paulo, 17 de set. de 2019. Disponível em: https://www1.folha.uol.com.br/esporte/2019/09/um-em-cadacinco-brasileiros-torce-para-o-flamengo-aponta-datafolha.shtml.

Original recebido em: 05 de abril de 2020

Aceito para publicação em: 20 de julho de 2021

Iago Maia Jornalista, especialista em Mídias Sociais pelo Centro Universitário Jorge Amado. Atua com métricas e Social Media.

Heitor Marback Administrador, Doutor em Difusão do Conhecimento pela UFBA. Atua como professor da especialização em mídias sociais do Centro Universitário Jorge Amado.

Rodrigo Ladeira Administrador e Doutor em administração, atua como professor da Faculdade de Administração da Universidade Federal da Bahia.

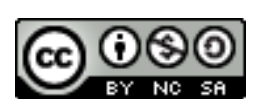

Esta obra está licenciada com uma Licença Creative Commons Atribuição-NãoComercial-CompartilhaIgual 4.0 Internacional 